\title{
Lecturer Support in the Implementation of a New Curriculum During the COVID-19 Pandemic
}

\author{
Tafirenyika Mafugu ${ }^{1}$ (D) Sanderson Abel $^{2}$
}

Received: 27 August 2021 / Accepted: 1 December 2021 / Published online: 5 January 2022

(C) The Author(s), under exclusive licence to Springer Nature B.V. 2021

\begin{abstract}
The objective of the study was to assess the support provided to lecturers in the implementation of a new curriculum during the COVID-19 pandemic to suggest early intervention strategies that address resources and knowledge deficiency gaps that have a negative impact on curriculum implementation. A survey design was used in the study. A representative sample of 30 lecturers was randomly selected from 5 Faculty of Natural Resources Management and Agriculture departments to complete the questionnaire between June and July 2020. The majority of the lecturers agreed that they were involved in the curriculum development. There was affirmation on the issue of professional development, leadership's support for lecturers' curriculum implementation and adequate time for curriculum implementation. Similarly, there was collaboration between university leadership and lecturers to plan curriculum implementation. On the contrary, funds for research necessary for curriculum implementation, instructional materials and supplies and technological resources were not adequately supplied. Hence, the paper becomes critical as it highlights the unavailability of technological resources which play a crucial role in online teaching and learning during the COVID-19 pandemic.
\end{abstract}

Keywords Curriculum implementation · Online teaching · COVID-19 pandemic . Instructional material

Tafirenyika Mafugu mafugut@ufs.ac.za

1 Department of Mathematics, Science and Technology Education, University of the Free State, Phuthaditjhaba, South Africa

2 Department of Agricultural Economics and Development, Midlands State University, Gweru, Zimbabwe 


\section{Introduction}

An educational curriculum is the conventional policy document by which a given society echoes its efforts and desires to bring about citizenship reform. It is the avenue through which socio-political expectations of the society are translated into knowledge, attitudes, values, and skills of learners within the school system are developed (Okebukola, 2005). The success of a curriculum depends on its implementation. The successful implementation of the curriculum depends on several factors. Therefore, there is a need to understand them to improve educational systems and outcomes. Lecturers have a mandate to implement an educational curriculum, and effective delivery depends on the quality of teaching and learning strategies, learning materials, and assessment. Lecturers who are properly trained can play an effective role in defining and implementing the curriculum. This entails understanding and participating in the curriculum development process, taking on new roles as advisors, facilitators, and curriculum developers. In this sense, lecturers cannot be taken for granted or viewed simply as skilled technicians who dutifully realize a given set of teaching in accordance with the directives of management. Lecturers are supposed to be active participants in the creation of classroom realities, and they act in the context of their own beliefs, attitudes and perceptions of the relevant teaching situation. The advent of COVID-19 has significantly changed the implementation of the curriculum in educational institutions. The current study seeks to assess the experiences encountered by lecturers in implementing a new curriculum during the COVID-19 pandemic in the Faculty of Agriculture, Environment and Natural Resources Management. The pandemic came into play when the government reviewed the educational system, moving from Education 3.0 (teaching, research, and community service) to Education 5.0 (teaching, research, community service, innovation and industrialization), thereby changing the mechanism of implementing the curriculum.

The study is significant since it is the first one of its kind in the Faculty of Agriculture, Environment and Natural Resources Management, looking at different experiences encountered in curriculum implementation during the COVID-19 pandemic. Since it focuses on implementing a new curriculum during the COVID-19 pandemic, the professional development of lecturers was a key component for successful implementation. New curriculum content and pedagogical skills required to teach during the COVID-19 pandemic triggered interest in the study. The process of how the new curriculum was implemented could provide important lessons to other institutions. They can learn from the successes and failures encountered during the implementation process.

The onset of the COVID-19 pandemic prompted the need for technological skills in implementing online teaching and learning. This calls for professional development among lecturers as well as training students in the use of the new technology. Several studies have been conducted to identify strategies for effective professional development of lecturers, which plays a pivotal role in new curriculum implementation (Avalos, 2011; Baird \& Clark, 2017; Garet et al., 2001; Penuel et al., 2007; Van Veen et al., 2010). Most of the studies were carried out in collaborative settings, 
which promote active learning dominated by sharing experiences, reflection, and activities focused on content knowledge (Borko, 2004; Brouwer et al., 2012; Stoll et al., 2006; Vescio et al., 2008).

For the successful implementation of these new tertiary curricula in the Faculty of Agriculture, Environment and Natural Resources Management, adequate professional development (PD) was needed to support lecturers in accommodating the new aspects of the innovative curriculum in their teaching practice (Almazova, et al., 2020; Marek, et al., 2021). According to Ball and Cohen (1996), curriculum materials could be a source of PD in content knowledge and pedagogy. Based on a study regarding lecturers using innovative units in the classroom, Hartshorne et al. (2020) and Marek et al. (2021) found that additional PD was needed to achieve the intended outcomes of curriculum innovation. Almazova et al. (2020) and Schuchardt et al. (2017) observed that the related need for additional PD in the new curriculum is mainly due to the differences in intended learning outcomes between the new and the previous curriculum.

The educational curriculum is a conventional policy document with objectives intended to deliver the content through a specified process by which a given society echoes its efforts and desires to bring about citizenship, reform, or maintain a tradition. The curriculum has always been the avenue through which socio-political expectations of the society are translated into knowledge, attitudes, values, and skills that transform learners within the school system (Okebukola, 2004). The government is a major influencer of the curriculum (Joseph, 2015). The government's involvement is geared towards the nation's socio-economic aspirations and preservation of its culture. Academic institutions draw significantly from the national economic blueprints in planning their curriculum (Joseph, 2015). In Zimbabwe, economic blueprints such as Economic Structural Adjustment Programme, Zimbabwe Programme for Economic and Social Transformation (ZIMPREST), Millennium Economic Recovery Programme (MERP), National Economic Revival Programme (NERP), National Economic Development Priority Programme (NEDPP), Short Term Emergency Recovery programme (STERP I), Medium Term Plan (MTP) and Zimbabwe Agenda for Sustainable Socio-Economic Transformation (ZIMASSET) have always shaped the curriculum in tertiary (Chigudu, 2015; Mapuva, 2017).

\section{Study Context}

The Faculty of Agriculture, Environment and Natural Resources Management at the Midlands State University is an innovative, leading, development-oriented faculty which produces globally recognized graduates for the empowerment of communities and creation of national capital stocks. The faculty is composed of four departments: Agricultural Economics and Development, Land and Water, Agronomy and crop production, and Animal and wildlife sciences. There are 58 lecturers in the faculty who are based on a full-time basis at the University and are not teaching in other universities. The student population is 945 in the whole faculty. Teaching in the faculty is traditionally done face-to-face in a classroom setup and 
through practical application in the agricultural practice section. The COVID-19 pandemic has brought changes to how the lectures are being conducted, with the virtual method taking precedence, while face-to-face is used for revision purposes before exams. The COVID -19 has led to the reduction in the number of hours students are in the agricultural practice section since students usually study from home. Another effect of the pandemic is that the work-related learning period has been reduced to six months instead of the traditional ten months. The work-related learning is equivalent to industrial attachment in other universities.

The faculty is critical to the university given it has a mandate of supporting the agricultural sector in the country and supervising four agricultural colleges that the government set up. The Faculty of Agriculture, Environment and Natural Resources Management ensures that the curriculum being implemented by these colleges is up to date with developments in the economy.

The Faculty of Agriculture, Environment and Natural Resources Management at the Midlands State University is one of the ten academic faculties mandated to deliver on various mandates. The Faculty of Agriculture, Environment and Natural Resources Management at the Midlands State University is mandated to produce graduates who will improve the agriculture sector in Zimbabwe and become entrepreneurs. The faculty boasts of farms and agricultural equipment meant to teach students modern methods of producing agricultural output.

The faculty is mandated with the running of the university farms in Gweru and Kwekwe producing products which are consumed internally, and sold on the open market. Within the faculty, the curriculum was developed in a way that ensures that all students are exposed to various agricultural activities. The faculty has specialized modules which are undertaken by the students in their different departments as well as faculty-wide modules undertaken by each student in the service department of agricultural practice. This ensures that all students who come from the faculty have a certain foundational knowledge of agricultural activities, which are practical. This is further buttressed by some common modules such as gender, entrepreneurship, and information technology which are taught university-wide. This assists all university students to appreciate the issues around gender mainstreaming, which is a global cross-cutting issue, as well as appreciate the use of technology; a must-have for every student.

\section{Curriculum Implementation}

A curriculum specifies what needs to be achieved and how it is going to be achieved (Kelly, 2008). Offorma (2005) opined that a curriculum is composed of three components, namely a program of studies, a program of activities, and guidance. Blenkin (2017) adds that the programme of study consists of content or subjects by which knowledge and skills are transmitted or delivered to learners by the most effective methods that can be devised. The curriculum acts as a catalyst for change and social development. According to Biggs and Tang (2015), the curriculum needs to achieve the desired goals. A constructive alignment is an outcomes-based approach that is based on the constructivist and curriculum theories. The constructivist theory views 
students as individuals who can construct their knowledge by engaging in activities (Biggs \& Tang, 2015). Curriculum theory posits that optimal learning is achieved when teaching and assessment activities align with learning outcomes (Biggs \& Tang, 2015).

Onyeachu (2008) notes that even if a curriculum is planned correctly and documented, the critical test for it lies with implementation. Onyeachu (2008) identifies implementation as a problematic aspect of the curriculum and is the key to successful innovation. Several studies have identified that curriculum implementation remains a challenge in education due to emerging new technologies (Aydin et al, 2017). A number of studies have identified that curriculum implementation remains a challenge in education since most aspects planned do not get implemented (Onyeachu, 2008; Ivowi, 2009; Olofu, 2003; Mkpa \& Izuagba 2009; Babalola 2004). Implementation connotes the operationalization of a well-articulated and wellintentioned idea presented as theory. The concept of curriculum implementation has been studied deeply by a number of authors (Ivowi, 2004; Onyeachu, 2008). Different authors have described curriculum implementation differently. Ivowi (2004) described curriculum implementation as the dissemination of a structured set of learning experiences, the provision of resources to effectively execute the plan, and the actual execution of the plan in the classroom setting where teacher-learner interactions occur. Mkpa and Izuagba (2009) highlighted that the curriculum implementation involving the learner for whom the programme is being planned interacts with the contents and materials to acquire the necessary skills, attitudes, and abilities. The process of curriculum implementation is that stage where the learner, through the guidance of a teacher, interacts with learning activities so as to maximize learning as will be noticed in the learners' new behaviour/new approach to issues. Onyeachu (2008) defined curriculum implementation as the process of putting all that has been planned as a curriculum document into practice in the classroom through the combined effort of the teacher, learners, school administrators, parents, as well as interaction with the physical facilities, instructional materials, and psychologicaland social environment. Babalola (2004) connotes that curriculum implementation is the multifarious activity of translating a complex curriculum conception in the form of a design or plan into new patterns of practical action, usable and realizable in a teaching-learning milieu. Okebukola (2005) notes that the intermediate steps in curriculum implementation include teaching through verbal and nonverbal exposition, practical work in laboratories, workshops and in the field, student-student interactions, student-material interactions and then evaluation and feedback. Olofu (2003) defined curriculum implementation as valid actions through participation, resource provision, or creating an enabling environment for the execution of a planned programme or translating theory into practice with a view of yielding expected results. Okello and Kagoire (1996) argue that curriculum implementation is a network of varying activities that translate curriculum design into classroom activities and change people's attitudes to accept and participate in these activities. However, curricula are faced with barriers that hinder the successful implementation of the curriculum. Curriculum developers, adopters, and implementers should be mindful of detractors such as these and address them adequately to minimize the impediments to curriculum implementation in learning institutions. 
However, curriculum implementations are faced with barriers, such as a lack of content and pedagogical knowledge, which hinder the successful implementation. Curriculum developers, adopters, and implementers should be mindful of detractors and must be prepared to address them adequately to minimize the impediments to curriculum implementation in learning institutions.

\section{Theoretical Framework}

Rogan and Grayson's (2003) framework of curriculum implementation was used in guiding the design of the research instrument and data analysis.

The framework of curriculum implementation consists of three main pillars or constructs, namely, outside support or influence, capacity to innovate, and a profile of implementation (Fig. 1). Each of the three pillars or constructs can be useful in understanding, analysing, and expressing the extent to which the principles of a curriculum, in this case the science learning area in the Faculty of Agriculture, Environment and Natural Resources Management, are being realized in this context. The pillar 'Outside Influences' consists of five sub-constructs: provision of resources required for innovation, professional development, types of change pressures, monitoring strategies and support to bear the pressure and direct support to learners. When resources are scarce and there is a lack of support such as professional development, lecturers reject implementing the new curriculum and continue teaching based on their initial frame of reference. Distantiation is caused by feelings

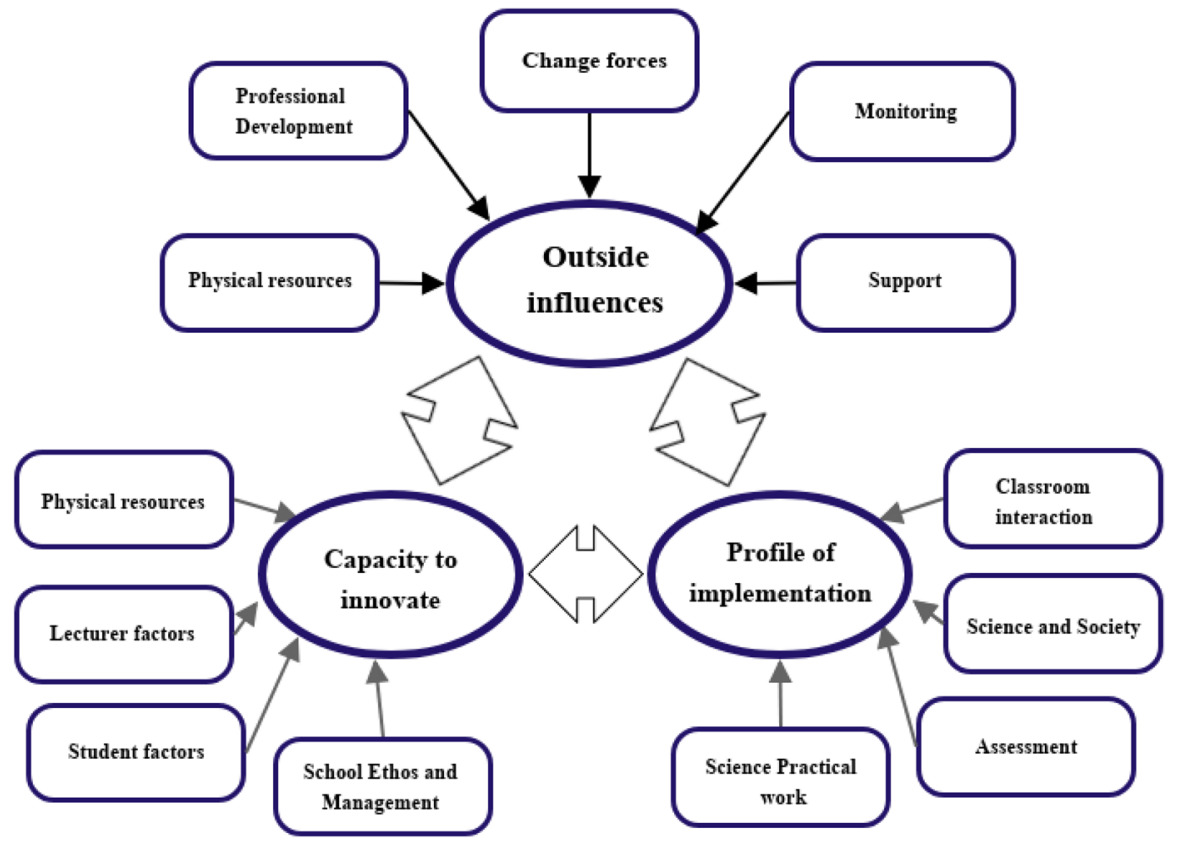

Fig. 1 Framework of curriculum implementation (Rogan \& Grayson, 2003) 
of uncertainty, stress, and incompetence, reducing lecturers' self-efficacy and selfesteem when implementing the new content (Brown \& Rodgers, 2002). According to Suchman (2003), the physical and cultural environments constitute a pivotal component to understanding what and how teachers make sense of new curriculum implementation. An unconducive, characterized by a lack of critical resources, may act as a key driver for distantiation. However, change forces such as COVID-19 may be the drivers for the change process.

The second construct, the 'Capacity to Innovate', consists of four sub-constructs: physical resources, teacher factors, learner factors, and school ethos and management. According to Dofing (2021), lecturers react differently when implementing a new curriculum. Spillane et al. (2002) believe that the ability of lecturers to act as agents of change in implementing a curriculum is closely related to their prior knowledge, expertise, experiences, the availability of resources, the nature of learners and the level of support rendered by the management team. The last construct, the 'Profile of Implementation', consists of four sub-constructs which are: the nature of classroom interaction; incorporation of science in society; assessment practices and use and nature of science practical work. According to Mafugu (2021), interactions and assessment assist in enhancing the learning process. Each subconstruct encompasses four levels, where level four represents learner-centred practices that are deemed to be sophisticated, while level one represents teacher-centred approaches. The levels present an array of practices that can be utilized in a classroom. The best choice is determined by the situation. For example, when classes are too large, the teacher-centred approach may be the best.

The study is arguably significant because it is the first one of its kind in the Faculty of Agriculture, Environment and Natural Resources Management to look at the different experiences encountered by the lecturers in curriculum implementation during the COVID-19 pandemic. Lectures have vast experience in implementing the curriculum, but most of these experiences have not been documented, leaving a substantial gap in academic knowledge. The study might also assist in re-looking at the curriculum implementation in the faculty and can further be generalized to the whole university. The study could be beneficial to the academic staff since it would highlight what needs to be done to achieve its desired objectives. Sharing experiences in the faculty is not the norm, and this has not been done for a long time. The results, therefore, would also be used to try and cultivate a culture where pertinent issues affecting the staff are discussed. The study was done at an opportune time when the university was moving from Education 3.0 to Education 5.0; hence it would help inform how the new curriculum could be successfully implemented, drawing from the opportunities and challenges that were experienced in implementing Education 3.0. Education 3.0 entailed that lecturer duties were defined in terms of teaching, research, and community service. Education 5.0 requires lectures to go beyond teaching, research and community service and further incorporate innovation and industrialization. More importantly, the study's results would, in the long run, assist in resolving the economic problems faced by the country in the sense that if today's youth possess the necessary desired skills and knowledge, they would, in no doubt, be capable of solving some economic challenges in the agricultural sector which anchors the Zimbabwean economy. 
How were lecturers supported in the implementation of a new curriculum during the COVID-19 pandemic?

\section{Research Methodology}

The research was underpinned by a survey research design. The use of a survey offers a greater advantage as increased numbers of people in society are resorting to the use of the Internet for communication and information (Nie et al., 2002). The online surveys allow a researcher to reach all participant lecturers in a short amount of time, despite being separated by pronounced geographic distances (Garton et al., 1999; Taylor, 2000). The researchers used a questionnaire as a data collection instrument, and utilized questions written in an organized, logical, systematic, and highly precise manner. The closed-ended Likert scale type questions requested participants to choose responses ranging from strongly disagree to agree strongly. The variables that were included in the questionnaire are shown in Table 1, in the results section. Pilot testing was done to improve the clarity of questions in the questionnaire. During pilot testing, the questionnaire was administered to ten lecturers in the Faculty of Science. Ambiguous questions were rectified.

A quantitative sample size " $n$ " was calculated using Slovin's formula: $n=N$ / $\left(1+\mathrm{Ne}^{2}\right) . \mathrm{n}=52 /\left[1+52(0.1)^{2}\right]=34.21 \sim 34$. Where $\mathrm{N}=$ sample size, $\mathrm{N}=$ total number of lecturers in the Faculty of Natural Resources Management and Agriculture, $\mathrm{E}=$ desired margin of error. Slovin's formula was used as it provides a reasonable estimate of the sample size (Ryan, 2013). A representative sample from each of the six departments was calculated using the formula: $m / 52(34)$, where $m=$ the total number of lecturers in each of the five departments in the Faculty of Natural Resources Management and Agriculture. The calculations yielded four respondents from the six members in the Department of Agricultural Economics and Development; nine participants from the 13 members in the Department of Agronomy and Horticulture and a similar number of participants from the Department of Lands and Water Management; six participants from the Department of Animal and Wildlife Sciences which had ten members, and six participants from the department of Agricultural Practice which also had ten members. The sample was selected using simple random sampling, where names were written on pieces of paper, mixed up in a hat from which the desired number of participants were randomly picked without looking into the hat. A total of 34 participants were selected from the five departments. However, one participant from four departments did not participate, leaving a total sample size of 30, which was still representative of the population size.

Table 1 Overall reliability test result

\begin{tabular}{ll}
\hline Cronbach's Alpha & N of Items \\
\hline 0.860 & 18 \\
\hline
\end{tabular}

Source own computation 
The questionnaire was sent via email. Each lecturer signed a consent form after reading through the details in line with the purpose of the study. Some of the lecturers were phoned and requested to participate in the survey. Phoning the participants raised the response rate.

The data were analyzed using the Statistical Package for the Social Sciences (SPSS) version 27. Descriptive statistics: frequencies, means, and standard deviations of lecturers' responses were generated based on the Likert scale data entered in SPSS. Spearman's rank correlation coefficients were calculated on questionnaire items that were readministered to determine the participants' responses' consistency. The data is presented in Table 3.

A reliability test was also conducted to ensure that the questionnaire could be depended upon to secure consistent results upon repeated application in future research studies. The reliability of the scale is the degree to which a set of items measure the same construct (Hair et al., 2010). According to Malhotra (2007), a scale is reliable if the Cronbach's alpha values are equal to or exceed the recommended threshold of 0.70 . From the computation of the Chronbach's alpha, a significantly notable overall statistic was observed for the questionnaire, while the alpha statistics for the variables under study was significantly higher than the minimum threshold of 0.70 . The results are shown in Tables 1 and 2.

Table 2 Item reliability

\begin{tabular}{|c|c|c|c|c|c|}
\hline & $\begin{array}{l}\text { Scale mean if } \\
\text { item deleted }\end{array}$ & $\begin{array}{l}\text { Scale variance if } \\
\text { item deleted }\end{array}$ & $\begin{array}{l}\text { Corrected item- } \\
\text { total correlation }\end{array}$ & $\begin{array}{l}\text { Squared multiple } \\
\text { correlation }\end{array}$ & $\begin{array}{l}\text { Cronbach's } \\
\text { alpha if item } \\
\text { deleted }\end{array}$ \\
\hline B1 & 47.10 & 80.239 & 0.189 & 0.919 & 0.865 \\
\hline B2 & 47.31 & 81.865 & 0.113 & 0.908 & 0.867 \\
\hline B3 & 47.34 & 83.163 & 0.040 & 0.814 & 0.870 \\
\hline B4 & 47.97 & 74.034 & 0.514 & 0.796 & 0.851 \\
\hline B5 & 48.00 & 72.786 & 0.575 & 0.867 & 0.848 \\
\hline B6 & 48.07 & 73.709 & 0.683 & 0.861 & 0.844 \\
\hline B7 & 48.14 & 71.052 & 0.578 & 0.701 & 0.848 \\
\hline B8 & 49.00 & 74.929 & 0.673 & 0.853 & 0.846 \\
\hline B9 & 47.93 & 74.281 & 0.511 & 0.740 & 0.851 \\
\hline B10 & 48.55 & 72.113 & 0.660 & 0.852 & 0.844 \\
\hline B11 & 48.79 & 74.527 & 0.655 & 0.807 & 0.846 \\
\hline B12 & 48.86 & 74.052 & 0.674 & 0.872 & 0.845 \\
\hline B13 & 48.62 & 77.315 & 0.406 & 0.838 & 0.855 \\
\hline B14 & 47.66 & 75.734 & 0.465 & 0.812 & 0.853 \\
\hline B15 & 48.00 & 74.929 & 0.513 & 0.760 & 0.851 \\
\hline B16 & 48.76 & 76.475 & 0.679 & 0.765 & 0.847 \\
\hline B17 & 48.69 & 81.579 & 0.161 & 0.616 & 0.864 \\
\hline B18 & 48.79 & 76.813 & 0.488 & 0.846 & 0.852 \\
\hline
\end{tabular}

Source own computation 


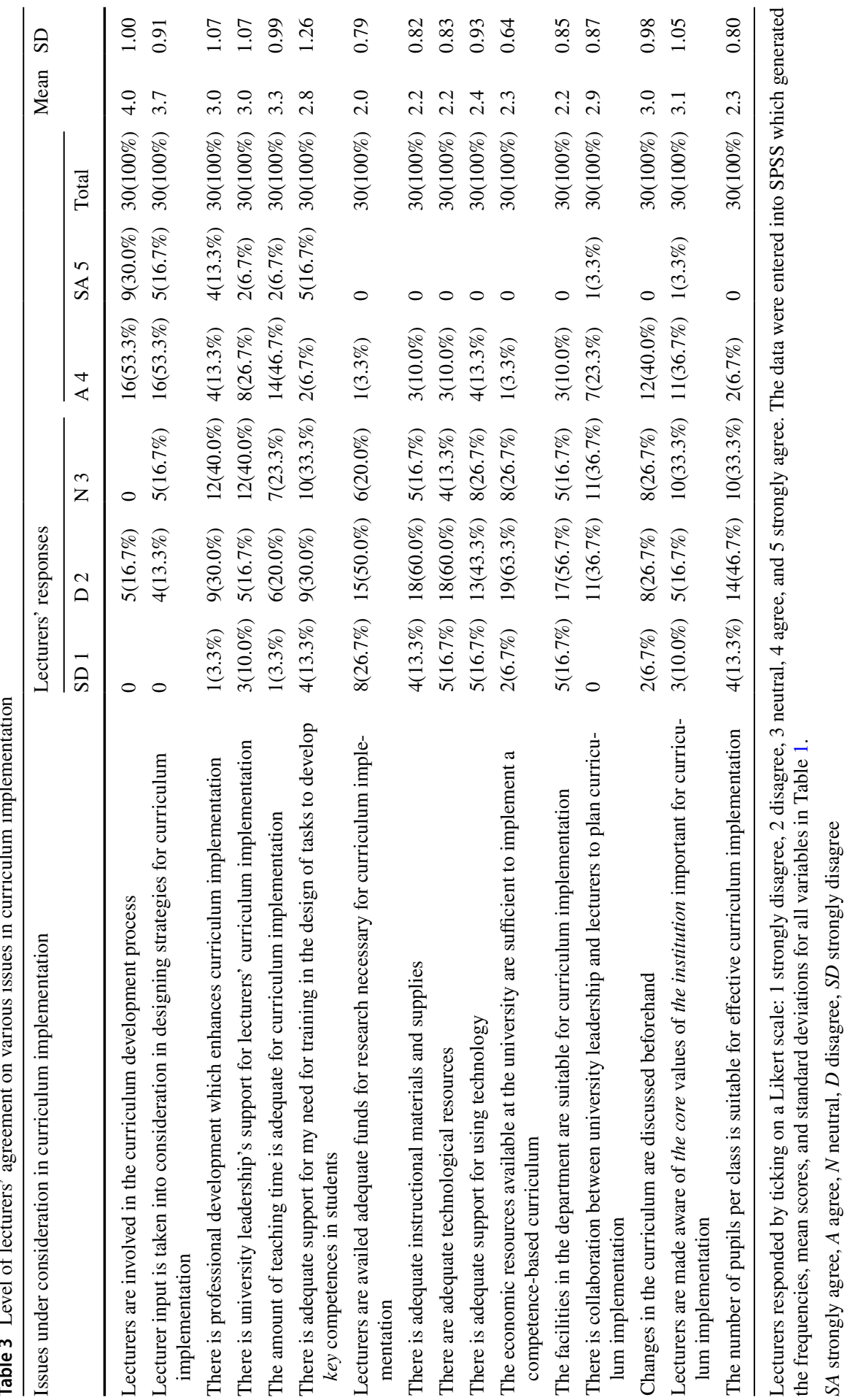


Ethical clearance was obtained from Midlands State University, and further permission was sought from the head of the department. The survey was then conducted in the five departments after informed consent from the participants.

\section{Study Results}

The results of the study are presented in texts and tables.

\section{Reliability Test Results}

Table 1 indicates that the reliability score for all items under study was above 0.70 , implying that the research instrument was reliable. The following table shows the reliability score if an item was deleted.

Table 2 reveals that the reliability scores for each of the 18 items in the Likert scale were above 0.7 , even after removing one of the items at a time. This means that all items captured in the questionnaire were valid and contributed to the understanding of the phenomena. This paves the way for the presentation and discussion of the finding.

\section{Lecturers' Experiences in Curriculum Implementation}

The summary of the results is shown in Table 3.

The majority of the lecturers agreed that they were involved in the curriculum development and implementation stages, and their input was considered (Mean $=4.0, \mathrm{SD}=1.0$, and Mean $=3.7, \mathrm{SD}=0.91$, respectively). A total of 25 lecturers either agreed or strongly agreed with this notion of involvement in curriculum development, while 21 shared the view that their input was considered in designing strategies for curriculum implementation. There is affirmation that there was professional development, leadership support for lecturers' curriculum implementation, and adequate time for curriculum implementation (Mean $=3.0, \mathrm{SD}=1.1$, Mean=3.0, $\mathrm{SD}=1.1$ and Mean=3.3, $\mathrm{SD}=0.99$ respectively). Similarly, there was a collaboration between university leadership and lecturers to plan curriculum implementation $(\mathrm{Mean}=2.9, \mathrm{SD}=0.87)$. However, funds for research necessary for curriculum implementation, instructional materials and supplies, and technological resources were not adequately supplied (Mean $=2.0, \mathrm{SD}=0.79$, Mean $=2.2$, $\mathrm{SD}=0.82$ and Mean $=2.2, \mathrm{SD}=0.83$ respectively). Regarding the number of pupils per class, the lecturers felt that the numbers were too high for effective curriculum implementation $($ Mean $=2.3, \mathrm{SD}=0.80)$. 


\section{Discussion}

The lecturers were involved in curriculum development and implementation, and their inputs were valued. The result concurs with Sidebotham et al.'s (2017) findings where participants felt that the positive experiences of individuals' added value to the curriculum. According to Taylor (2003) and Caldwell et al. (2012), the participation of lecturers in curriculum development creates a partnership among stakeholders, promotes shared ownership of the curriculum, and improves the potential of effective implementation. The framework for curriculum implementation by Rogan and Grayson (2003) holds the view that the lecturer plays a pivotal role in curriculum implementation. This is supported by Spillane et al. (2002), who argue that the ability of lecturers to act as agents of change in implementing a new curriculum is closely related to their prior knowledge, expertise, experience, availability of resources, the nature of students and the level of support rendered by the management team. The study's respondents also affirmed that they got the necessary leadership, collaboration, and support regarding implementation time, although $33.3 \%$ of the participants disagreed that there was adequate professional development to ensure effective curriculum implementation. Professional development increases confidence, competency, reduces stress, and increases lecturers' self-efficacy and self-esteem when implementing the new content (Brown \& Rodgers, 2002). The study by Baird and Clark (2017) posits that professional development support improves the effectiveness of the implementation process. Hence, there is a need to source adequate funding from the government and non-governmental organizations to support the professional development of lecturers. According to the sense-making model, involving lecturers in the curriculum development process would enable them to see aspects of the new curriculum that match lecturers' knowledge, skills, attitudes, and beliefs about teaching in the knowledge domain (Luttenberg et al., 2013). As the lecturers participate, areas that need professional development can be highlighted to the management to ease the planning process. Professional development enables them to adapt to new aspects in ways that match their personal frame of reference. The adaptation results in a variation of existing aspects within their frame of reference.

There were challenges in terms of research funding necessary for curriculum implementation. Instructional materials and supplies and technological resources were also not adequately supplied.

A shortage of such critical resources during the time of the pandemic has a seriously negative impact on teaching and learning. The COVID-19 pandemic increased the need for new resources for online teaching and learning. The implementation of a new curriculum during the COVID-19 pandemic could have exacerbated the shortage of resources since new pedagogical approaches were to be adopted. In addition, the lecturer-to-pupil ratio was too low. Ginsburg et al. (2017) observed a lack of financial resources in curriculum implementation in low-income and middle-income countries. Shiel and Jones (2016) and Johnson et al. (2004) view detailed project planning, including careful planning for acquiring resources such as instructional materials as essential steps for successfully implementing the curriculum. Several 
studies (Buller \& McEvoy, 1989; Gray, 1997; Green \& Plsek, 2002) have found top management support for innovations, a primary factor in sustaining innovation. Lack of technological resources could have severe implications during the COVID-19 pandemic since the pandemic imposed a ban on face-to-face instruction (Alghamdi, 2021). According to the sense-making aspect of accommodation, lecturers should transform their frame of reference to match the new aspects in the new curriculum (Luttenberg et al., 2013). They gain experience in teaching the new aspects and reflect on their experiences. They learn from the reflection. They need to find possibilities to expand their current practise by including new aspects in pedagogy. Management needs to provide adequate resources and in-service training programmes for lecturers to become competent in using technology. The lecturers can also share the skills among themselves to improve their competencies. However, in the current situation where there is no technical support, lecturers will find it challenging to teach the new curriculum with inadequate support for online learning. According to the sense-making model, lecturers who are not supported with adequate technological resources may reject implementing the new curriculum and continue teaching based on their initial frame of reference. This feeling of distantiation is caused by a lack of adequate resources, which reduces lecturers' self-efficacy and self-esteem when implementing the new content using new pedagogical skills (Brown \& Rodgers, 2002). According to Suchman (2003) and Rogan and Grayson (2003), the physical environment that lacks adequate resources in this particular instance constitutes a key impediment in implementing a new curriculum. An unconducive environment, characterized by a lack of critical resources, acts as a key driver for distantiation.

\section{Conclusions}

The study has established that curriculum implementation suffers from a number of challenges in the Faculty of Agriculture, Environment and Natural Resources Management. These challenges are handicapping the lecturers in delivering on their main mandate, which is to disseminate knowledge to the students. The challenges are multidimensional in nature, ranging from a national, university-wide, facultyspecific, and department-specific. National challenges such as an economic meltdown which has led to water shortages and intermittent electricity shortages, have a considerable bearing on the learning and teaching environment, hence causing a strain on the implementation of the curriculum. Inflation is also causing the erosion of staff salaries, demotivating them from working, as the employer cannot afford an inflation adjustment. The university administration is failing to provide lecturers with the relevant required material, including technological equipment and consumables such as markers and bond paper, which sometimes leaves the lecturers to source their own materials. The faculty of Natural Resources Management has been affected by high staff turnover, which has exacerbated the workload of the teaching staff. 


\section{Recommendations}

Considering the foregoing discussion, the study recommends that the curriculum implementation process should be adequately resourced. The lectures should always have the requisite material to ensure that they successfully implement the curriculum. Universities should provide lecturers with projectors, laptops, adequate research funding, and Internet resources which are prerequisites for successful curriculum implementation. There is a need to provide professional development courses to lecturers to equip them with new pedagogical skills and content knowledge, including online teaching and learning platforms and online assessment. In addition, the universities should invest in alternative sources of energy such as solar power, so that when electricity is cut-a normal phenomenon in the country-institutions could switch to the alternative source, therefore ensuring that there is continuous power. Curriculum development is a continuous process. Given the rapid changes internationally, there is a need to constantly review the curriculum implementation mechanisms in line with current global trends.

Funding The project was not funded.

Data Availability The data is available on request.

\section{Declarations}

Conflict of interest The authors declare no conflict of interest.

Ethical Approval The research was approved by the ethical clearance committee of Midlands State University.

\section{References}

Alghamdi, A. A. (2021). Impact of the COVID-19 pandemic on the social and educational aspects of Saudi university students' lives. PLoS ONE. https://doi.org/10.1371/journal.pone.0250026

Almazova, N., Krylova, E., Rubtsova, A., \& Odinokaya, M. (2020). Challenges and opportunities for Russian Higher Education amid COVID-19: Teachers' perspective. Education Sciences, 10(12), 368.

Avalos, B. (2011). Teacher professional development in teaching and teacher education over ten years. Teaching and Teacher Education, 27(1), 10-20. https://doi.org/10.1016/j.tate.2010.08.007

Aydin, H., Ozfidan, B., \& Carothers, D. (2017). Meeting the challenges of curriculum and instruction in school settings in the United States. Journal of Social Studies Education Research, 8(3), 76-92.

Babalola, V. O. (2004). Resource Materials in the Implementation of Curriculum in 21st Century. In A. O. K. Noah, D. O. Shonibare, A. A. Ojo \& T. Olajuwon (Eds.), Curriculum implementation and professional teaching in Nigeria. Lagos: Central Educational Services.

Baird, T. J., \& Clark, L. E. (2017). The "look-ahead" professional development model: A professional development model for implementing new curriculum with a focus on instructional strategies). Professional Development in Education, 44(3), 326-341. https://doi.org/10.1080/19415257.2017.13084 24

Biggs, J., \& Tang, C. (2015). Constructive alignment: An outcomes-based approach to teaching anatomy. In L. Chan \& W. Pawlina (Eds.), Teaching anatomy. Cham: Springer. 
Blenkin, G. M., \& Geva, M. (2017). Change and the curriculum. Sage.

Borko, H. (2004). Professional development and teacher learning: Mapping the terrain. Educational Researcher, 33(8), 3-15.

Brouwer, P., Brekelmans, M., Nieuwenhuis, L., \& Simons, P. R. (2012). Fostering teacher community development: A review of design principles and a case study of an innovative interdisciplinary team. Learning Environments Research, 15(3), 319-344. https://doi.org/10.1007/s10984-012-9119-1

Brown, J. D., \& Rodgers, T. S. (2002). Doing second language research. Oxford University Press.

Buller, P. F., \& McEvoy, G. M. (1989). Determinants of planned organizational change. Group and Organization Studies, 14(1), 33-50. https://doi.org/10.1177/105960118901400105

Caldwell, C., Dixon, R. D., Floyd, L. A., Chaudoin, J., Post, J., \& Cheokas, G. (2012). Transformative leadership: Achieving unparalleled excellence. Journal of Business Ethics, 109(2), 175-187. https:// doi.org/10.1007/s10551-011-1116-2

Chigudu, D. (2015). Navigating policy implementation gaps in Africa: The case of Zimbabwe. Risk Governance and Control: Financial Markets and Institutions, 5(3), 7-14. https://doi.org/10.22495/rgcv5 i3art1.

Dolfing, R., \& Gjalt, I, Prins, T., Bulte, A. M. W., Pilot, A., \& Vermunt, J. D. (2021). Strategies to support teachers' professional development regarding sense-making in context-based science curricula. Science Education, 105, 127-165. https://doi.org/10.1002/sce.21603

Garet, M. S., Porter, A. C., Desimone, L., Birman, B. F., \& Yoon, K. S. (2001). What makes professional development effective? Results from a national sample of teachers. American Educational Research Journal, 38(4), 915-945. https://doi.org/10.3102/00028312038004915

Garton, L., Haythornthwaite, C., \& Wellman, B. (1999). Studying on-line social networks. In S. Jones (Ed.), Doing internet research: Critical issues and methods for examining the net (pp. 75-105). Sage.

Ginsburg, L. R., Dhingra-Kumar, N., \& Donaldson, L. J. (2017). What stage are low-income and middle-income countries (LMICs) at with patient safety curriculum implementation and what are the barriers to implementation? A two-stage cross-sectional study. BMJ Open, 7(6), 1-10. https:// doi.org/10.1136/bmjopen-2017-016110

Gray, P. J. (1997). Viewing assessment as an innovation: Leadership and the change process. In: P. J. Gray, \& T. W. Banta (Eds.), New directions for higher education, No. 100, pp. 5-15. San Francisco: Jossey-Bass.

Green, P. L., \& Plsek, P. E. (2002). Coaching and leadership for the diffusion of innovation in health care: A different type of multi-organization improvement collaborative. Journal on Quality Improvement, 28(2), 55-71. https://doi.org/10.1016/S1070-3241(02)28006-2

Hair, J., Black, W., Babin, B., \& Anderson, R. (2010). Multivariate data analysis: A global perspective (7th Ed). New York: Pearson.

Hartshorne, R., Baumgartner, E., Kaplan-Rakowski, R., Mouza, C., \& Ferdig, R. E. (2020). Special issue editorial: Preservice and inservice professional development during the COVID-19 pandemic. Journal of Technology and Teacher Education, 28(2), 137-147.

Ivowi, U. M. O. (2004). Curriculum implementation: Implication for school administration. In Noah, A. O. K., Shonibare, D. O., Ojo, A. A. and Olujuwon, T. (Eds) curriculum implementation and professionalizing teaching in Nigeria. Lagos: Central Educational Services.

Johnson, K., Hays, C., Center, H., \& Daley, C. (2004). Building capacity and sustainable prevention innovations: A sustainability planning model. Evaluation and Program Planning, 27(2), 135149. https://doi.org/10.1016/j.evalprogplan.2004.01.002

Joseph, S.-. (2015). Curriculum politics in higher education: What educators need to do to survive. International Journal of Higher Education, 4(3), 14-20. https://doi.org/10.5430/ijhe.v4n3p14

Kelly, A. V. (2008). The curriculum theory and practice (4th ed.). Paul Chapman.

Luttenberg, J., Imants, J., \& van Veen, K. (2013). Reform as ongoing positioning process: The positioning of a teacher in the context of reform. Teachers and Teaching: Theory and Practice, 19(3), 293-310. https://doi.org/10.1080/13540602.2012.75416

Mafugu, T. (2021). The impact of peer-peer learning and student-lecturer interaction on Biology pre-service teachers' achievements. Cypriot Journal of Educational Sciences, 16(2), 511-521. https://doi.org/10.18844/cjes.v16i2.5629

Marek, M. W., Chew, C. S., \& Wu, W. V. (2021). Teacher experiences in converting classes to distance learning in the COVID-19 pandemic. International Journal of Distance Education Technologies (IJDET), 19(1), 89-109. https://doi.org/10.4018/IJDET.20210101.oa3 
Mapuva, J. (2017). Zimbabwe's Economic Interventionist Policies: Critical Issues and Perspectives. The African Review: A Journal of African Politics, Development and International Affairs, 44(2), 29-49.

Mkpa, M. A., \& Izuagba, A. C. (2009). Curriculum studies and innovation. Owerri: Divine Mercy Publishers.

Nie, N., Hillygus, S., \& Elbring, L. (2002). Internet use, interpersonal relations and sociability: Findings from a detailed time diary study. In $\mathrm{B}$. Wellman (Ed.), The internet in everyday life (pp. 215-243). Blackwell Publishers.

Offorma, D. (2005). A critical appraisal of mode of implementation of Nigerian Secondary School curriculum: Towards socio-economic empowerment of youth. Paper presented at the seminar of the World Council for Curriculum and Instruction (WCCI), held at the Federal College of Education, Kano, Nigeria.

Okebukola P. (2005). The teacher: A basic fundamental unit in National development. The teacher a book of reading.

Okello, V., \& Kagoiren, M. A. (1996). Makerere University, Curriculum Studies Module. Kampala: Bezatel Design Studies.

Olofu, M. A. (2003). Introduction to the fundamentals of curriculum development. Ushie Printers \& Publishing Co., Ltd.

Onyeachu, E. (2008). Teachers characteristics and school curriculum implementation in Nigeria Secondary Schools: A theoretical review in Journal of the Nigerian Academy of Education. Nigeria Jonahed, 1, 118-120.

Penuel, W. R., Fishman, B. J., Yamaguchi, R., \& Gallagher, L. P. (2007). What makes professional development effective? Strategies that foster curriculum implementation. American Educational Research Journal, 44(4), 921-958. https://doi.org/10.3102/0002831207308221

Rogan, J. M., \& Grayson, D. (2003). Towards a theory of curriculum implementation with particular reference to science education in developing countries. International Journal of Science Education, 25, 1171-1204. https://doi.org/10.1080/09500690210145819

Ryan, T. P. (2013). Sample size determination and power. Wiley.

Saiyad, S., Virk, A., Mahajan, R., \& Singh, T. (2020). Online teaching in medical treining: Establishing good online teaching practices from cumulative experience. International Journal of Applied \&amp; Basic Medical Research, 10(3), 149-155. https://doi.org/10.4103/ijabmr.IJABMR_358_20

Schuchardt, A. M., Tekkumra-Kisa, M., Schunn, C. D., Stein, M. K., \& Reynolds, B. (2017). How much professional development is needed with educative curriculum materials? It depends upon the intended student learning outcomes. Science Education, 101(6), 1015-1033. https://doi.org/10. 1002/sce. 21302

Shiel, C., \& Jones, D. (2016). Sustainability and social justice: Leadership challenges Assembling and Governing the Higher Education Institution (pp. 11-34). Palgrave Macmillan.

Sidebotham, M., Walters, C., Chipperfield, J., \& Gamble, J. (2017). Midwifery participatory curriculum development: Transformation through active partnership. Nurse Education in Practice, 25, 5-13. https://doi.org/10.1016/j.nepr.2017.04.010

Spillane, J. P., Reiser, B. J., \& Rermer, T. (2002). Policy implementation and cognition: Reframing and refocusing implementation research. Review of Educational Research, 72, 387-431. https://doi.org/ $10.3102 / 00346543072003387$

Stoll, L., Bolam, R., McMahon, A., Wallace, M., \& Thomas, S. (2006). Professional learning communities: A review of the literature. Journal of Educational Change, 7(4), 221-258. https://doi.org/10. 1007/s10833-006-0001-8

Suchman, M. C. (2003). The contract as social artifact. Law and Society Review, 37(1), 91-142.

Taylor, H. (2000). Does Internet research work? Comparing electronic survey results with telephone survey. International Journal of Market Research, 42(1), 51-63.

Taylor, P. (2003). How to design a training course: A guide to participatory curriculum development. VSO/Continuum.

Van Veen, K., Zwart, R., Meirink, J., \& Verloop, N. (2010). Professional development of teachers: A review study about the effective characteristics of professional development interventions. ICLON/ Centre of Expertise in Teacher Learning.

Vescio, V., Ross, D., \& Adams, A. (2008). A review of research on the impact of professional learning communities on teaching practice and student learning. Teaching and Teacher Education, 24(1), 80-91. https://doi.org/10.1016/j.tate.2007.01.004 
Publisher's Note Springer Nature remains neutral with regard to jurisdictional claims in published maps and institutional affiliations. 